\title{
A mononucleotide repeat in PRRT2 is an important, frequent target of mismatch repair deficiency in cancer
}

\author{
Inês Teles Alves ${ }^{1,2}$, David Cano ${ }^{2}$, René Böttcher ${ }^{1}$, Hetty van der Korput ${ }^{2}$, Winand \\ Dinjens' ${ }^{2}$, Guido Jenster ${ }^{1}$, Jan Trapman ${ }^{2}$ \\ ${ }^{1}$ Department of Urology, Erasmus MC, Rotterdam, The Netherlands \\ ${ }^{2}$ Department of Pathology, Erasmus MC, Rotterdam, The Netherlands \\ Correspondence to: Guido Jenster, email: g.jenster@erasmusmc.nl
}

Keywords: PRRT2, mismatch repair, mononucleotide repeat, prostate cancer, colorectal cancer

Received: November 22, $2015 \quad$ Accepted: October 21, $2016 \quad$ Published: November 19, 2016

\section{ABSTRACT}

The DNA mismatch repair (MMR) system corrects DNA replication mismatches thereby contributing to the maintenance of genomic stability. MMR deficiency has been observed in prostate cancer but its impact on the genomic landscape of these tumours is not known. In order to identify MMR associated mutations in prostate cancer we have performed whole genome sequencing of the MMR deficient PC346C prostate cancer cell line. We detected a total of 1196 mutations in PC346C which was 1.5-fold higher compared to a MMR proficient prostate cancer sample (G089). Of all different mutation classes, frameshifts in mononucleotide repeat (MNR) sequences were significantly enriched in the PC346C sample. As a result, a selection of genes with frameshift mutations in MNR was further assessed regarding its mutational status in a comprehensive panel of prostate, ovarian, endometrial and colorectal cancer cell lines. We identified PRRT2 and DAB2IP to be frequently mutated in MMR deficient cell lines, colorectal and endometrial cancer patient samples. Further characterization of PRRT2 revealed an important role of this gene in cancer biology. Both normal prostate cell lines and a colorectal cancer cell line showed increased proliferation, migration and invasion when expressing the mutated form of PRRT2 ( $\triangle P R R T 2)$. The wild-type PRRT2 (PRRT2 ${ }^{\text {wt }}$ ) had an inhibitory effect in proliferation, consistent with the low expression level of PRRT2 in cancer versus normal prostate samples.

\section{INTRODUCTION}

DNA mismatch repair (MMR) is a highly conserved repair mechanism responsible for the correction of mismatched base pairs occurring during the DNA replication process [1]. Defects in this repair mechanism are associated with mutations in microsatellite repeat sequences [2], which consist of tandemly repeated motifs of one (mono) to six (hexa) nucleotides [3]. The mismatch repair heterodimers MSH2/MSH6 and MSH2/ MSH3 detect replication errors and recruit the MLH1/ PMS2 complex which in turn degrades and resynthesizes the mutated stretch [4]. When MMR is defective, these errors will not be corrected and will lead to frequent microsatellite instability (MSI) [2].

Most microsatellite sequences are located in non-coding DNA with limited consequences to cell functions [5]. But recently, defects in MMR were shown to originate a mutator phenotype with an increased rate of frameshift mutations in genes including those with coding microsatellites [6]. Affected genes are involved in signal transduction pathways (TGFBRII, IGFIIR and $P T E N)$ [7-9], apoptosis (BAX and CASP5) [10, 11], DNA repair $(M B D 4)$ [12], and transcriptional regulation (TCF-4, EPHB2, AXIN2) [13-15]. The proteins resulting from these frameshift mutations can contribute to tumour progression by functional inactivation, a dominant negative effect, or a gain of function [16-18].

Germline mutations in MMR genes are present in over $90 \%$ of Lynch syndrome patients, which are characterized by MSI and an increased risk of colorectal cancer and several other cancer types [19]. The MSI phenotype is also observed in approximately $15 \%$ of sporadic colorectal cancers [20], 12\% of ovarian cancers [21], $20 \%$ of endometrial cancers [22, 23], 30\% of gastric cancers [24] and less frequent in other cancer types [25]. 
MMR deficiency is also frequent in in vitro growing prostate cancer cell lines. LNCaP cells do not express MSH2 due to gene deletion and MLH1 is mutated in DU145, resulting in expression of an unstable truncated MLH1 protein [26, 27]. The frequency of MSI reported in prostate cancer patients varies considerably between different studies but it is conclusively lower than in other sporadic cancer types [28, 29].

So far, no whole genome sequencing study has focused on identifying novel genes commonly targeted by MMR deficiency in prostate cancer. Whole genome sequencing of two prostate cancer samples, one with a functional MMR system (G089, a late stage prostate cancer patient) and other with deficiency of the MMR system (PC346C, a prostate cancer cell line with point mutations in both alleles of the $\mathrm{MSH} 2$ gene) [30] identified numerous novel gene mutations. Mutations in mononucleotide repeats (MNR) were most specific for the PC346C sample. A set of 17 candidate genes with mutations in MNR was defined and further evaluated in a larger panel of prostate, colorectal, endometrial and ovarian cancer cell lines. We identified proline-rich transmembrane protein 2 (PRRT2) and DAB2 interacting protein $(D A B 2 I P)$ to be frequently mutated in all different cancer cell line types. Further analysis showed that both genes were also frequently mutated in colorectal and endometrial cancer patient samples. Functional studies revealed PRRT2 to be implicated in cellular proliferation and migration with the truncated MSI-derived PRRT2 form promoting both processes.

\section{RESULTS}

\section{Overview of microsatellite mutations in gene sequences}

To identify novel gene mutations caused by MMR deficiency in prostate cancer, we analyzed the whole genome sequence of the MMR-deficient prostate cancer cell line PC346C and the MMR-proficient prostate cancer patient sample (G089). We selected for mutations that would likely disrupt the normal protein function (insertion/deletion introducing frameshifts, and mutations in the start or stop codon). The sequence flanking each gene mutation (10 nucleotides up and downstream) was retrieved using the UCSC genome browser. We selected for mutations occurring in microsatellite sequences in the PC346C sample and absent in G089, thereby enriching for mutations that are caused by MMR deficiency. First, the type and length of repeats were used to attain an overview of the mutation spectrum in both prostate cancer samples (Figures 1A, 1B and 1C). We included in our studies repeats with three or more repeat units, depending on the repeat composition (mono-, di- or tri-nucleotide repeat). Overall, we detected 1196 gene mutations in PC346C and
760 gene mutations in G089 (Supplementary Tables 1 and 2). From the 1196 gene mutations in PC346C, 303 were in mononucleotide repeats (MNRs), 79 in dinucleotide repeats (DNRs) and 19 intrinucleotide repeats (TNRs) ( $6 \mathrm{x} \mathrm{n}_{1}$ for MNR, $3 \times \mathrm{n}_{2}$ for DNR and $3 \mathrm{x} \mathrm{n}_{3}$ for TNR) (Supplementary Figure 1A). In G089, 47 gene mutations were in MNRs, 56 in DNRs and 19 in TNRs $\left(6 \mathrm{x} \mathrm{n}_{1}\right.$ for MNR, $3 \mathrm{x} \mathrm{n}_{2}$ for DNR and $3 \mathrm{x} \mathrm{n}_{3}$ for TNR) (Supplementary Figure 1B).

PC346C had a 1.5-fold increase in the number of mutated genes as compared to G089. The number of mutations found in MNR sequences of 6 nucleotides was 6-fold higher in PC346C. A 6-fold increase in MNR gene mutations in PC346C was also observed for MNRs of length $\mathrm{n}_{8}$. Since MNRs showed, compared to di- and tri-nucleotide repeats, a higher incidence of mutations in $\mathrm{MSI}+$ cancers we focused on these repeats.

We separated the mutated genes in PC346C and G089 in A, T, C and G MNRs categories of different lengths (Supplementary Table 3). The UCSC build hg18 was used as reference for gene annotation. The number of $\mathrm{C}$ and $\mathrm{G} M \mathrm{MNR}$ in reference genes was considerable lower than that of $\mathrm{A}$ and $\mathrm{T}$ repeats. As expected the mutations in $\mathrm{C}$ and G MNRs in PC346C and G089 was also much lower than that of A and T MNRs (Supplementary Table 3).

\section{Novel target genes of microsatellite instability}

To specifically select novel gene mutations associated with MMR deficiency with expected functional impact we first filtered for mutations in MNR sequences in PC346C, which were 6 nucleotides or longer. We excluded LOC annotated gene symbols and genes already known to be associated with MMR deficiency or MSI by using the text mining software Anni 2.0. (http://biosemantics.org/ index.php/software/anni). We identified over 35 mutated genes in PC346C, which were already known as targets of MSI or are associated with MMR deficiency including TGFBRII, PTEN, BAX, MLH3, MSH6 and MSH2. The frequent identification of known MMR-associated genes confirmed the validity of our approach. This procedure left 119 genes for further selection. Next, Ingenuity Pathway Analysis (IPA) was used to identify genes with functions most likely to be cancer-associated, like cell cycle, cellular growth, apoptosis and other important cell signaling pathways. Finally, we checked the expression profile of candidate genes using Affymetrix exon array data of 90 prostate cancer RNA samples and 17 normal controls (Supplementary Materials and Methods). A final subset of 14 novel genes showing MNR mutations and differential expression between normal and prostate cancer samples was assessed for their mutation status in a larger panel of cancer cell lines (Table 1). As positive controls we added three known MSI target genes (PHACTR4, MLL3 and CEP164). 


\section{Frequency of microsatellite instability target genes}

Microsatellite status of the set of target genes was examined in three MMR-proficient prostate cancer cell lines and in four MMR-deficient prostate cancer cell lines (Figure 2, Supplementary Table 4, Supplementary Figure 2). None of the MMR-proficient prostate cancer cell lines showed MSI in the selected gene panel. Controls CEP164, PHACTR4 and MLL3 were mutated in two or more of the MMR-deficient cell lines. We found that CNOT1, DAB2IP and PRRT2 were mutated in at least three MMR-deficient cell lines (Figure 2, Supplementary Table 4).

Next, we expanded the cell line panel with ten colorectal, four endometrial and three ovarian cancer MMR-deficient cell lines together with control MMRproficient cell lines of each cancer type. As observed in the MMR-proficient prostate cancer cell lines, colorectal, endometrial and ovarian cancer MMR-proficient cell lines showed no mutations in the analysed genes (Table 2 and Supplementary Table 5). The control genes CEP164, PHACTR4 and MLL3 displayed as expected high mutation frequencies, ranging from $30 \%$ to $80 \%$ in the MSI cancer cell lines (Table 2 and Supplementary Table 5). Also here we identified CNOT1, DAB2IP and PRRT2 as novel MSI target genes, in the MMR-deficient cancer cell lines, although with varying frequency. The genes displayed mostly deletions and to a lesser extend insertions (Table 2 and Supplementary Table 5). The mutations shifted the open reading frame of the affected genes and consequently predicted to result in synthesis of truncated proteins due to premature termination (Supplementary Table 1). CNOT1 contains a $\mathrm{n}_{13} \mathrm{~A}$ repeat in the open reading frame located 10 nucleotides upstream of the stop codon. A frameshift mutation at this position might not be critical for the protein and no further research was conducted for this gene. The $\mathrm{n}_{9} \mathrm{C}$ repeat in PRRT2 and the $\mathrm{n}_{8} \mathrm{C}$ repeat in $D A B 2 I P$ displayed a mutation pattern reflecting both insertions and deletions. (Supplementary Figure 3A, 3B).

\section{Frequency of $P R R T 2$ and $D A 2 I P$ repeat mutations in MSI patient cancer samples}

Next, we checked whether the mutation frequencies of PRRT2 and DAB2IP observed in the cancer cell line
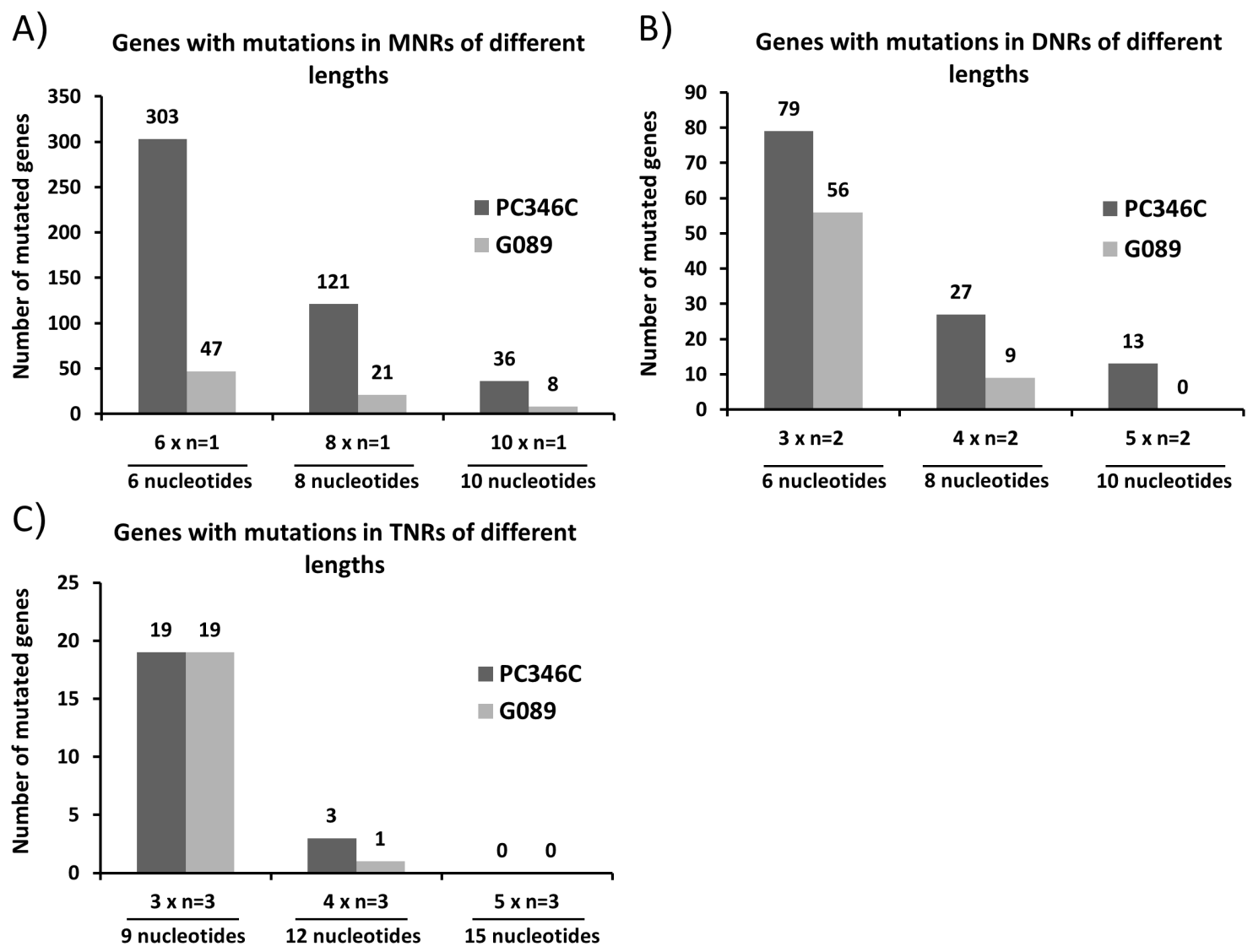

Figure 1: Overview of the mutation spectrum in G089 and PC346C genomic DNA. Genes with mutations in mononucleotide repeats (MNRs) A., dinucleotide repeats (DNRs) B. and trinucleotide repeats (TNRs) C. were distributed according to the length of the mutated repeat sequence. The repeat unit length for MNRs is one nucleotide $(n=1)$, for DNRs it is two nucleotides $(n=2)$ and for TNRs it is three nucleotides $(n=3)$. The $x$-axis shows the number of repeat units: 6,8 and 10 in case of MNRs; $3 x$, $4 x$ and $5 x$ in case of DNRs and TNRs. 
Table 1: List of microsatellite instability target genes in PC346C

\begin{tabular}{|c|c|c|c|}
\hline Gene & Name & Length of repeat & Mutation in PC346C \\
\hline CNOT1 & CCR4-NOT transcription complex, sub 1 & A13 & $\operatorname{del} \mathrm{AA}$ \\
\hline DAB2IP & DAB2 interacting protein & $\mathrm{C} 8$ & del C \\
\hline PRRT2 & proline-rich transmembrane protein 2 & $\mathrm{C} 9$ & ins $\mathrm{CC}$ \\
\hline TTC3 & tetratricopeptide repeat domain 3 & A8 & $\operatorname{del} \mathrm{A}$ \\
\hline CEP164 & centrosomal protein $164 \mathrm{kDa}$ & A11 & $\operatorname{del} \mathrm{A}$ \\
\hline PHACTR4 & phosphatase and actin regulator 4 & A10 & $\operatorname{del} \mathrm{A}$ \\
\hline TROVE2 & TROVE domain family, member 2 & A9 & $\operatorname{del} A$ \\
\hline ZFR & zinc finger RNA binding protein & T9 & del T \\
\hline MLL3 & myeloid/lymphoid or mixed-lineage leukemia 3 & T9 & del T \\
\hline ANLN & anillin, actin binding protein & A7 & $\operatorname{del} \mathrm{A}$ \\
\hline ANUBL1 & AN1, ubiquitin-like, homolog & A7 & $\operatorname{del} \mathrm{A}$ \\
\hline EPRS & glutamyl-prolyl-tRNA synthetase & T6 & ins $\mathrm{T}$ \\
\hline KCNMA1 & $\begin{array}{l}\text { potassium large conductance calcium-activated } \\
\text { channel, subfam } M, \alpha 1\end{array}$ & T9 & $\operatorname{del} \mathrm{T}$ \\
\hline PDS5A & $\begin{array}{l}\text { PDS5, regulator of cohesion maintenance, homolog } \\
\text { A (S. cerevisiae) }\end{array}$ & A6 & $\operatorname{del} \mathrm{A}$ \\
\hline SFRS12IP1 & SFRS12-interacting protein & $\mathrm{T} 10$ & ins $\mathrm{T}$ \\
\hline TSHZ2 & teashirt zinc finger homeobox 2 & $\mathrm{C} 7$ & del C \\
\hline USP42 & ubiquitin specific peptidase 42 & A8 & $\operatorname{del} \mathrm{A}$ \\
\hline
\end{tabular}

Genes are ordered first by the frequency of mutation in MMR deficient prostate cancer samples and second alphabetically. The 3 MMR associated genes used as a positive control are depicted in red.

A)
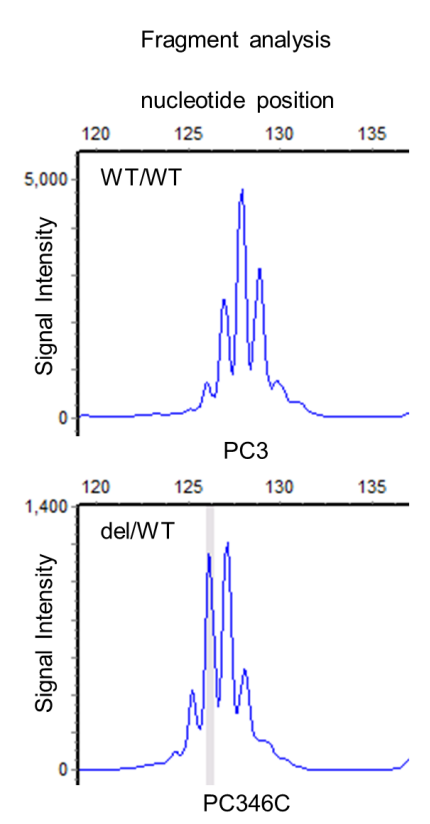

B)
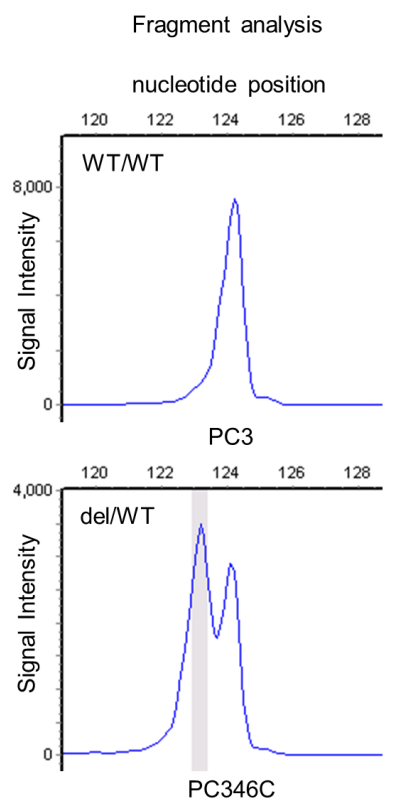

C) $\quad$ PRRT2
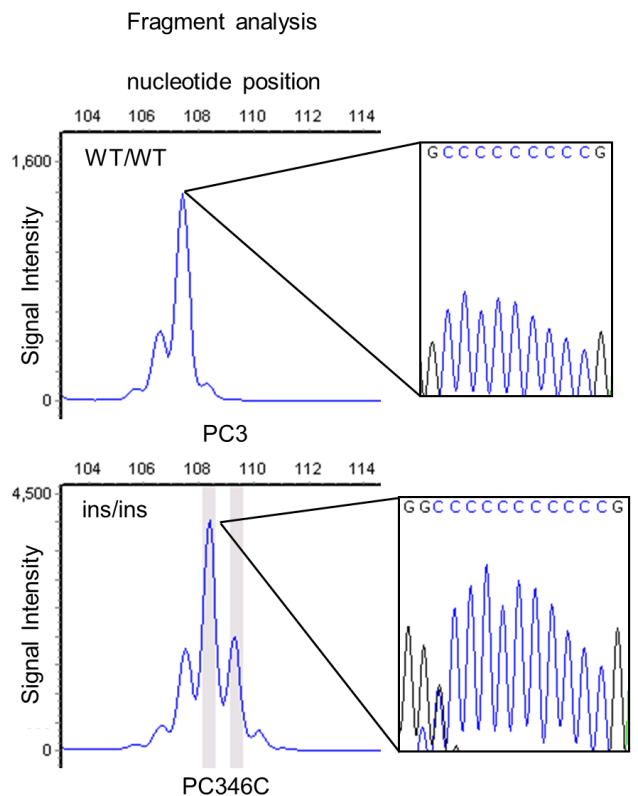

Figure 2: MNR repeat analysis of top mutated genes in prostate cancer in genomic DNA from prostate cancer cell lines PC346C (MMR deficient) and PC3 (MMR proficient). Fragment size analyses of PCR amplified fragments of CNOT1 A., $D A B 2 I P$ B. and PRRT2 C. containing the repeat are presented. The highlighted peaks represent a mutant allele. PCR primers are presented in supplementary data. WT: wild type; del: deletion; ins: insertion. Indicated PRRT2 PCR fragments are flanked by sequence analysis of the repeat. 
Table 2: Number of MSI positive (MSI) and negative (MSS) prostate, colorectal, endometrial and ovarian cancer cell lines with mutations in the set of MSI target genes in PC346C

\begin{tabular}{|c|c|c|c|c|c|c|c|c|}
\hline & \multicolumn{2}{|c|}{ Prostate Cancer } & \multicolumn{2}{|c|}{ Colorectal Cancer } & \multicolumn{2}{|c|}{ Endometrial Cancer } & \multicolumn{2}{|c|}{ Ovarian Cancer } \\
\hline & MSS & MSI & MSS & MSI & MSS & MSI & MSS & MSI \\
\hline CNOT1 & $0 / 3$ & $4 / 4$ & $0 / 3$ & $9 / 10$ & $0 / 3$ & $4 / 4$ & $0 / 2$ & $1 / 3$ \\
\hline DAB2IP & $0 / 3$ & $3 / 4$ & $0 / 3$ & $6 / 10$ & $0 / 3$ & $1 / 4$ & $0 / 2$ & $0 / 3$ \\
\hline PRRT2 & $0 / 3$ & $3 / 4$ & $0 / 3$ & $4 / 10$ & $0 / 3$ & $4 / 4$ & $0 / 2$ & $2 / 3$ \\
\hline TTC3 & $0 / 3$ & $2 / 4$ & $0 / 3$ & $5 / 10$ & $0 / 3$ & $1 / 4$ & $0 / 2$ & $0 / 3$ \\
\hline CEP164 & $0 / 3$ & $3 / 4$ & $0 / 3$ & $8 / 10$ & $0 / 3$ & $3 / 4$ & $0 / 2$ & $2 / 3$ \\
\hline PHACTR4 & $0 / 3$ & $3 / 4$ & $0 / 3$ & $7 / 10$ & $0 / 3$ & $3 / 4$ & $0 / 2$ & $1 / 3$ \\
\hline TROVE2 & $0 / 3$ & $1 / 4$ & $0 / 3$ & $5 / 10$ & $0 / 3$ & $4 / 4$ & $0 / 2$ & $1 / 3$ \\
\hline ZFR & $0 / 3$ & $2 / 4$ & $0 / 3$ & $4 / 10$ & $0 / 3$ & $3 / 4$ & $0 / 2$ & $1 / 3$ \\
\hline MLL3 & $0 / 3$ & $2 / 4$ & $0 / 3$ & $8 / 10$ & $0 / 3$ & $3 / 4$ & $0 / 2$ & $1 / 3$ \\
\hline ANLN & $0 / 3$ & $1 / 4$ & $0 / 3$ & $0 / 10$ & $0 / 3$ & $0 / 4$ & $0 / 2$ & $0 / 3$ \\
\hline ANUBL1 & $0 / 3$ & $1 / 4$ & $0 / 3$ & $2 / 10$ & $0 / 3$ & $0 / 4$ & $0 / 2$ & $0 / 3$ \\
\hline EPRS & $0 / 3$ & $1 / 4$ & $0 / 3$ & $0 / 10$ & $0 / 3$ & $0 / 4$ & $0 / 2$ & $0 / 3$ \\
\hline KCNMA1 & $0 / 3$ & $1 / 4$ & $0 / 3$ & $6 / 10$ & $0 / 3$ & $1 / 4$ & $0 / 2$ & $1 / 3$ \\
\hline PDS5A & $0 / 3$ & $1 / 4$ & $0 / 3$ & $0 / 10$ & $0 / 3$ & $1 / 4$ & $0 / 2$ & $0 / 3$ \\
\hline SFRS12IP1 & $0 / 3$ & $1 / 4$ & $0 / 3$ & $6 / 10$ & $0 / 3$ & $2 / 4$ & $0 / 2$ & $1 / 3$ \\
\hline TSHZ2 & $0 / 3$ & $1 / 4$ & $0 / 3$ & $10 / 10$ & $0 / 3$ & $3 / 4$ & $0 / 2$ & $3 / 3$ \\
\hline USP42 & $0 / 3$ & $1 / 4$ & $0 / 3$ & $4 / 10$ & $0 / 3$ & $4 / 4$ & $0 / 2$ & $0 / 3$ \\
\hline
\end{tabular}

The 3 control genes are depicted in red. Three MSS cell lines were available for prostate, colorectal and endometrial cancer and one MSS cell line for ovarian cancer. The number of MSI cell lines available for prostate, colorectal, endometrial and ovarian cancer were four, ten, four and three respectively.

panels could be confirmed in primary cancer samples. We tested a total of 80 prostate cancer patient samples, including late stage and metastasised cancers. None of the samples displayed the mutations in either of the genes (data not shown), not unexpected because MSI is not frequent in clinical prostate cancer. Further, we tested 24 colorectal and 24 endometrial MSI patient cancer samples. We found PRRT2 to be mutated in 15 out of 24 colorectal cancer patients and in 11 out of 24 endometrial cancer patients (Supplementary Figure 4, Supplementary Table 6). Although the mutation frequency in the DAB2IP MNR was similar (11/23), only one endometrium cancer sample displayed a mutation in the repeat. To further evaluate the significance of the mutation frequency of PRRT2 and DAB2IP in clinical MSI colorectal and endometrial cancer patient samples, we compared their frequency to the average mutation frequency for common MSI target genes published in databases (SelTarbase [31]) (Supplementary Table 7). Compared to other genes, PRRT2 displayed a very high mutation frequency in both colorectal and endometrial cancer and was selected for functional studies.

\section{The PRRT2 gene}

PRRT2 encodes a 340 amino acids protein that has two predicted transmembrane domains. This protein is poorly characterised, although recently a link between PRRT2 mutations and a rare neurological disease, paroxysmal kinesigenic dyskinesia, was established [32]. Whether PRRT2 has a role in cancer is unknown. Frameshifts in the C-repeat would result in expression of truncated proteins of 222 or 227 amino acids that lack the predicted transmembrane domains (Figure 3A). The PC346C prostate cancer cell line is the only cell line we identified, which has a mutation in both PRRT2 alleles. To investigate a possible role of $P R R T 2$ in cancer we first documented PRRT2 expression levels by RNA sequencing in available cancer data sets (Supplementary Materials and Methods). Overall, PRRT2 showed a consistent decrease in expression in cancer as compared to normal in prostate, lung and gastric tissue samples (Figures 3B, 3C, 3D). Both lung and gastric cancers have been associated with MSI. In order to exclude non-mediated mRNA decay of the mutated PRRT2 transcript we investigated the expression 
level of PRRT2 in PC346C. The elevated expression level detected suggested that the stability of the PRRT2 transcript is not affected by the mutation (Supplementary Figure 5).

\section{Biological activity of PRRT2}

To assess whether the truncated PRRT2 ( $\triangle$ PRRT2) influenced cell proliferation, we stable transfected the normal prostate epithelial cell line PNT2C2 with lentiviral constructs expressing wild type PRRT2 (PRRT2wt) or $\triangle$ PRRT2. Efficiency of transfection was assessed by the expression of GFP, independently transcribed under the CMV promoter. Cell proliferation was measured during 4 days after plating of equal numbers of control (GFP only), PRRT2 $^{\text {wt }}$ and $\triangle$ PRRT2 transfected cells.

A significant increase in proliferation capacity of PNT2C2 cells expressing $\triangle$ PRRT2 (37.5\%) was observed as compared to the control cells at day 8 . Conversely, the growth of PNT2C2 cells expressing PRRT2 ${ }^{\text {wt }}$ was impaired

B)

) PRRT2 expression in a prostate cancer

\section{A) PRRT2 wildtype and truncated protein}

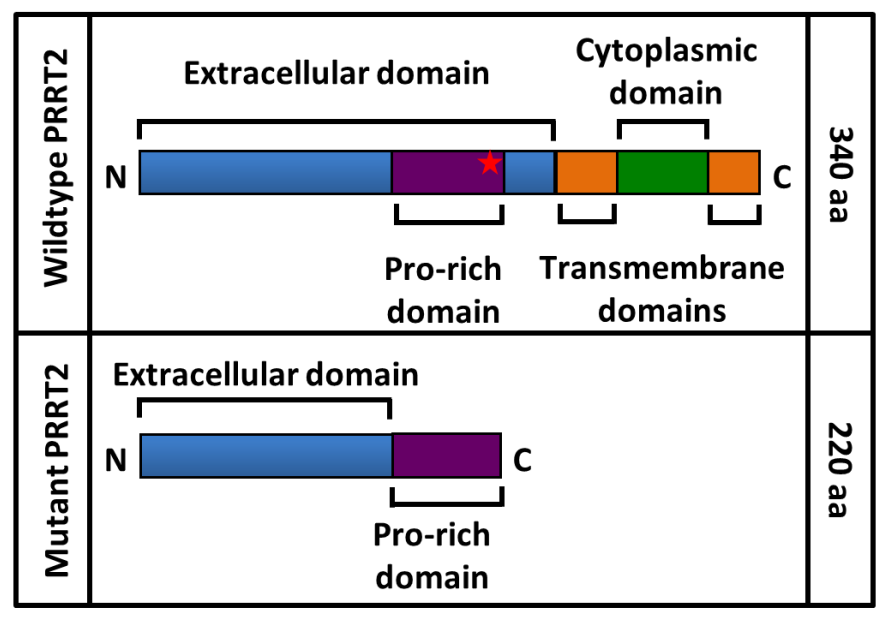

\section{C) PRRT2 expression in a lung cancer dataset}

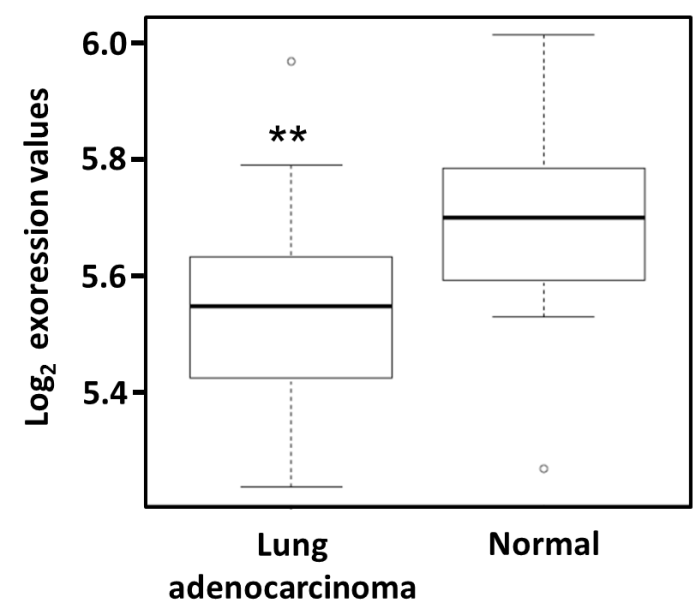
dataset

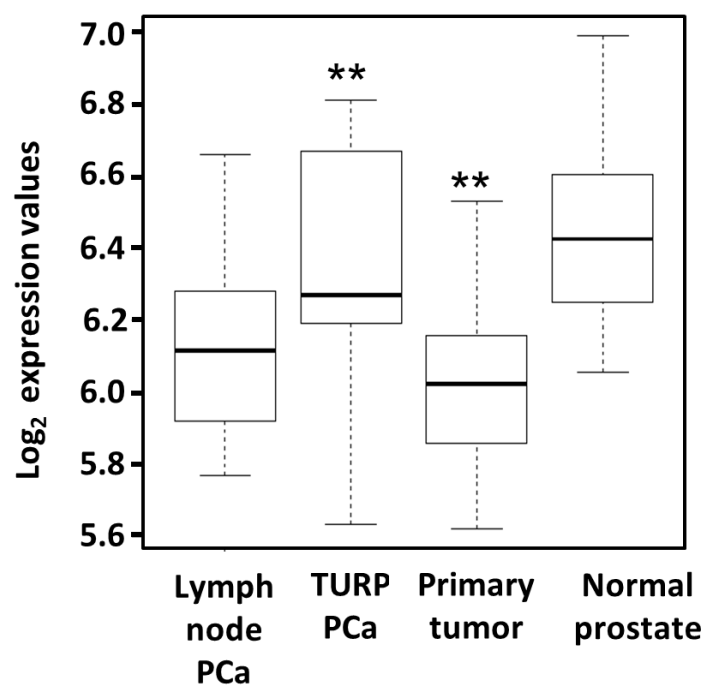

D)
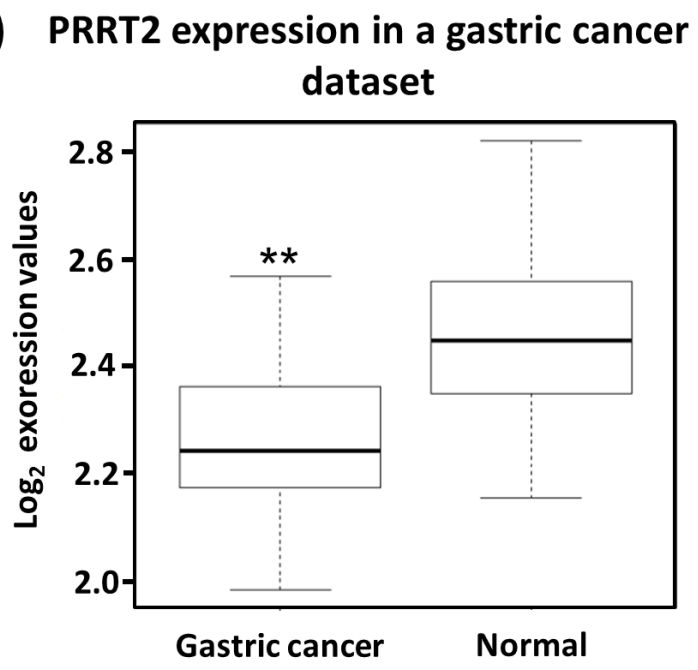

Figure 3: Expression pattern of PRRT2 mRNA. A. Schematic representation of the wildtype and the mutant PRRT2. The insertion of $\mathrm{C}$ and $\mathrm{CC}$ in the $9 \mathrm{C}$ repeat of $\mathrm{PC} 346 \mathrm{C}$ leads to a truncated protein lacking the predicted transmembrane and cytoplasmatic domains. The frameshift occurs within the proline-rich region of PRRT2. B. Box plot analysis of PRRT2 mRNA in prostate cancer lymph node metastasis (LN-PCa, 12 samples), transurethral resections (TURP- PCa, 10 samples), primary prostate cancer (PCa, 56 samples) and normal adjacent prostate tissue (NAP, 12 samples). C. Expression levels of PRRT2 in lung adenocarcinoma (22 samples) and normal lung tissue (22 samples). D. Expression levels of PRRT2 in gastric cancer (20 samples) and normal gastric tissue (20 samples). Wilcoxon testing was used in (B), (C) and (D) to determine significant differences in expression levels. 
especially as compared to the PNT2C2 cells expressing $\triangle$ PRRT2 (Figure 4A). The $\triangle$ PRRT2 effect on cellular proliferation was further validated in the RWPE-1 prostate epithelial cell line and the HCT116 colorectal cancer cell line. Both cell lines displayed the same growth promoting effect of $\triangle$ PRRT2. RWPE-1 cells stably expressing $\triangle P R R T 2$ showed an increase of $20 \%$ in proliferation capacity whereas PRRT2 ${ }^{\mathrm{wt}}$ did not stimulate proliferation (Figure 4B). HCT116 cells expressing $\triangle$ PRRT2 showed an increase of $41 \%$ in proliferation capacity as compared to the control. Similar to PNT2C2, cells expressing PRRT2 ${ }^{\mathrm{wt}}$ showed a decrease in cellular proliferation (Figure 4C). The cell cycle analysis of HCT116 and PNT2C2 cells revealed an increase in the percentage of cells in S-phase when $\triangle$ PRRT2 is present (Figure 4D and Supplementary Table 8).

The influence of PRRT2 expression on apoptosis was addressed in a caspase $3 / 7$ activation assay in all $\triangle$ PRRT2 and PRRT2 ${ }^{\text {wt }}$ expressing cell lines described above. In none of the cases we observed a clear difference in apoptosis levels between $\triangle$ PRRT2, PRRT2 ${ }^{\text {wt }}$ and control GFP expressing cells (data not shown).

A)

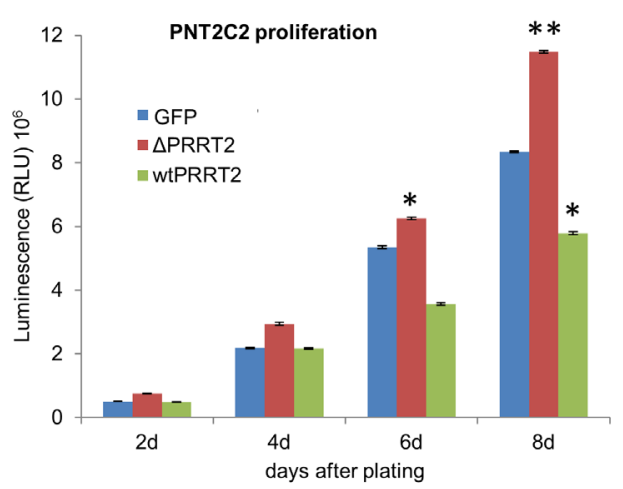

C)

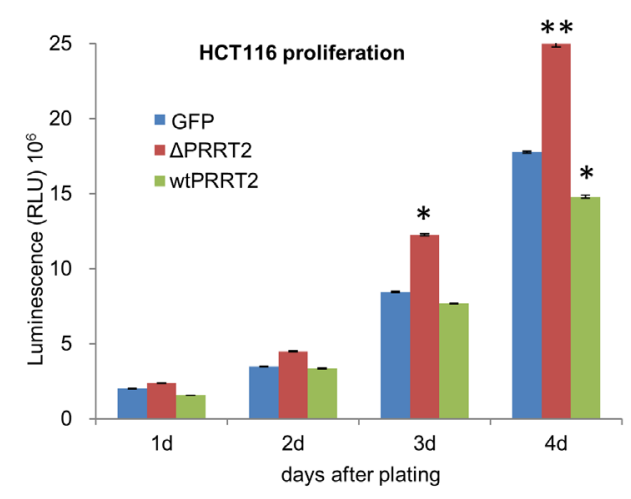

Finally we addressed the effect of PRRT2 on cell migration and invasion. PNT2C2, RWPE-1 and HCT116 expressing $\triangle$ PRRT2, PRRT2 ${ }^{\text {wt }}$ and GFP were cultured in migration chambers for $24 \mathrm{~h}$ in both presence and absence of $10 \%$ FCS. We detected a significant increase in migratory capacity of $\triangle \mathrm{PRRT} 2$ expressing cells as compared to the GFP controls (Figure 5A and 5B). Migration of PRRT2 ${ }^{\text {wt }}$ expressing cells was consistently lower than the GFP control cells, but in all cases, not significantly different. In order to determine whether PRRT2 also promotes cell invasion we cultured PNT2C2 and HCT116 cells expressing $\triangle$ PRRT2, PRRT2 ${ }^{\text {wt }}$ and GFP in collagen invasion chambers during 24h. Again, $\triangle$ PRRT2 expressing cells were more invasive compared to GFP and PRRT2 ${ }^{\text {wt }}$ expressing cells. (Figure 5C and 5D).

\section{DISCUSSION}

\section{Microsatellite instability in cancer}

The most prominent characteristic allowing cancer cells to survive, proliferate and disseminate is the

B)

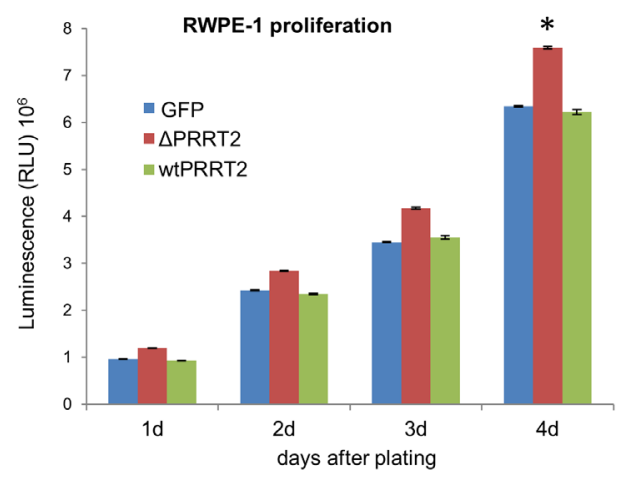

D)

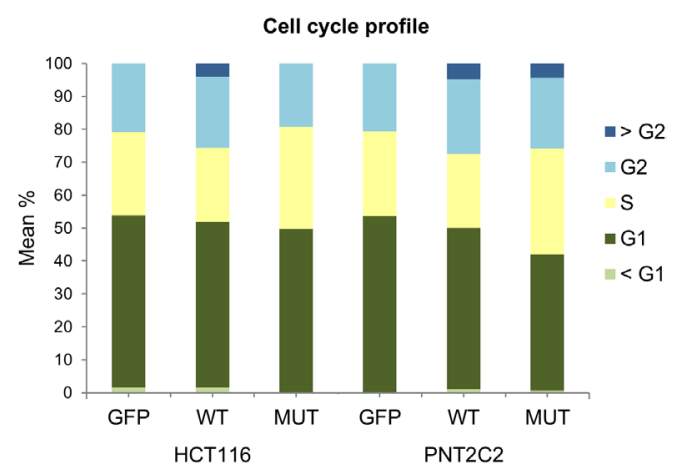

Figure 4: PRRT2 affects cellular proliferation. A. PNT2C2, B. RWPE-1 and C. HCT116 cells were stably transduced with lentiviral vectors expressing the truncated form of PRRT2 ( $\triangle$ PRRT2), the wildtype PRRT2 (wtPRRT2) and the control GFP vector. Cellular proliferation was measured 1, 2, 3 and 4 days after plating of the RWPE-1 and HCT116 cells, and 2, 4, 6 and 8 days after plating of the PNT2C2 cells. Cellular viability was measured by the reduction of luciferin into ocyluciferin in the presence of ATP. The $y$-axis displays the RLU (relative light units). Asterisks indicate $* \mathrm{P} \leq 0.02$ and $* * \mathrm{P} \leq 0.002$, respectively, in a two-tailed Student's t-test. D. The cell cycle profile of HCT116 and PNT2C2 cells expressing GFP, $\triangle$ PRRT2 and wtPRRT2 was determined measuring PI staining levels by flow cytometry. 
development of genomic instability [33]. DNA repair mechanisms are the cells' surveillance systems and defects in this machinery are responsible for accelerating the rate at which cells can accumulate favourable genotypes. The MMR system eliminates base-base mismatches and insertion-deletion loops that arise during DNA replication due to slippage of the DNA polymerase [1]. Simple repetitive DNA sequences known as microsatellites are particularly prone to insertions and deletions due to defective MMR [34]. As a result, cells with a defective MMR system might have mutation rates 100-1000 fold higher than normal cells [35]. Several studies have shown that instability of microsatellites is present in $\mathrm{PCa}[36,37]$. The frequency of microsatellite instability detected in $\mathrm{PCa}$ is variable between different studies and ranges from $8 \%$ [38] to $35 \%[39,40]$. To elucidate the role of MMR in PCa we have sequenced the complete genome of the MMRdeficient PC346C cell line. This cell line was derived from a transurethral resection of a primary tumor and lacks a functional MSH2 protein due to point mutations in both alleles [30].

The use of whole genome sequencing allowed an unbiased detection of all gene mutations and it is a powerful strategy to uncover genes implicated in the disease. Using this approach we identified a total of 1196 gene mutations in PC346C. Approximately one third of these mutations occurred in nucleotide repeat sequences (see also ref [41]). The total number of gene mutations detected in G089 was 1.5 fold lower than in PC346C, which fits to the mutational phenotype due to MMR deficiency. Mutations in MNRs were enriched by 6-fold in PC346C as compared to G089. The bias in MNR mutations in PC346C as compared to G089 was used to select for gene mutations triggered by the MMR system. Several of the downstream target genes of MMR deficiency have shown to be key players in proliferation and apoptosis pathways.
A)

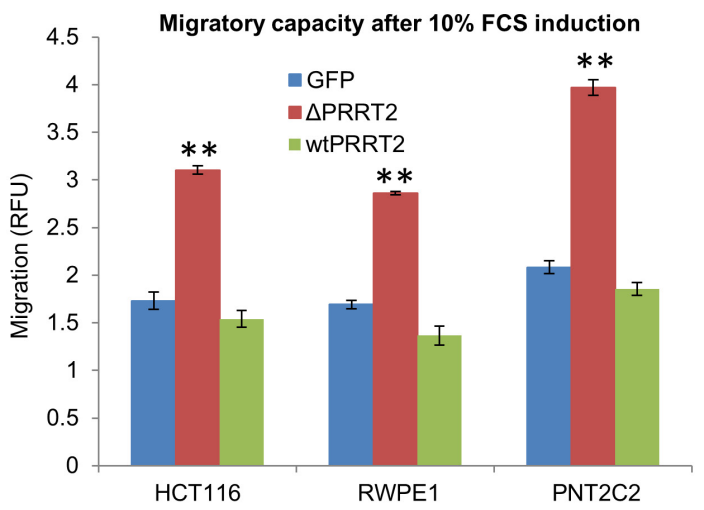

C)

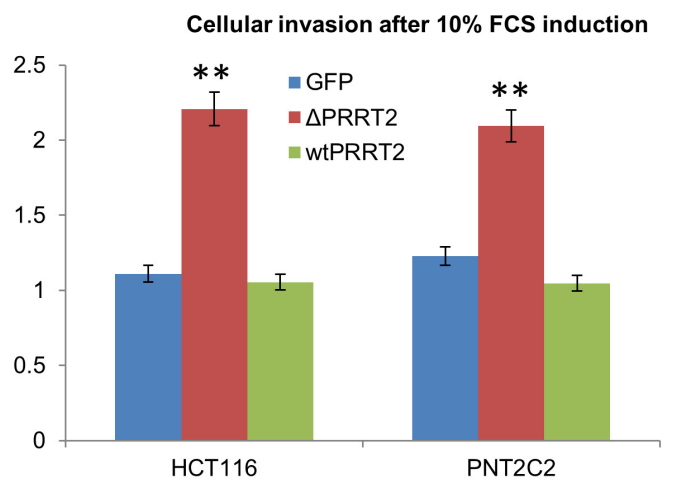

B)

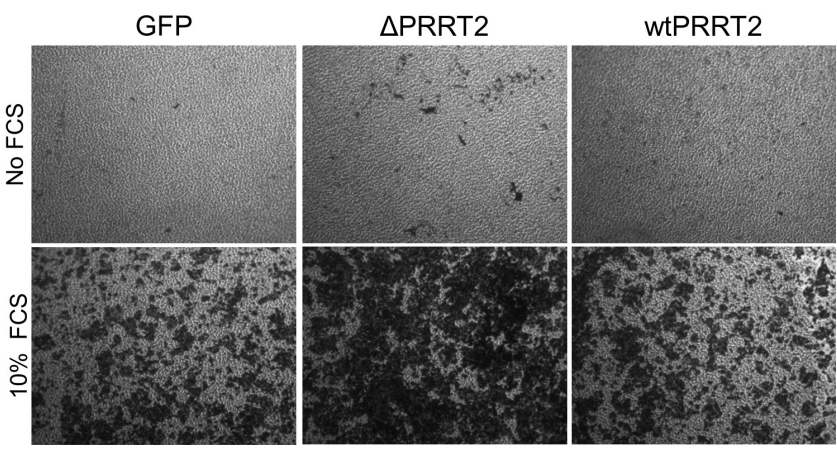

D)

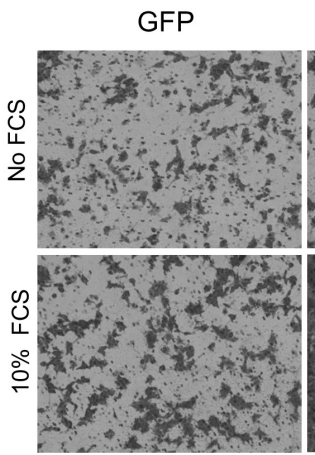

$\triangle \mathrm{PRRT2}$

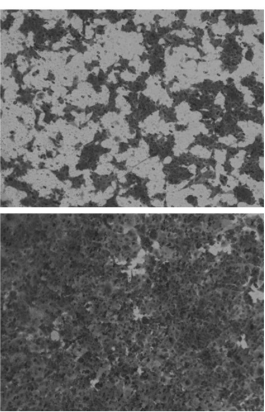

wtPRRT2

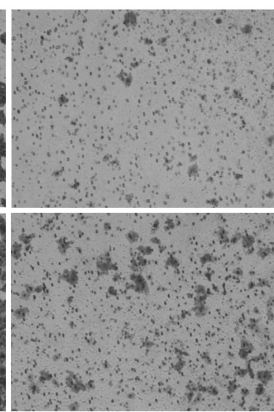

Figure 5: PRRT2 plays a role in cellular migration and invasion. A. Migratory capacity of HCT116, PNT2C2 and RWPE-1 cells was assayed by measuring the cells migrating through a $5 \mu \mathrm{m}$ polycarbonate membrane. Migration was induced by $10 \%$ FCS. Cells were assayed using CyQuant ${ }^{\circledR}$ GR fluorescent dye. All samples were normalized to the fluorescent detection in the absence of chemo attractant $\left(10 \%\right.$ FCS). RFU represents the relative fluorescent units. ${ }^{* *} \mathrm{P} \leq 0.002$ was calculated using a two-tailed Student's t-test. B. Representative illustrations of migration of HCT116 cells expressing $\triangle$ PRRT2, wtPRRT2 or control GFP in the presence and absence of $10 \%$ FCS (see also legend to Figure 4). C. Cellular invasion of HCT116 and PNT2C2 cells was assayed using collagen-coated membranes. Invasion was induced by $10 \%$ FCS. Cells were assayed using the same method as for migration. D. Representative illustrations of invasion of HCT116 cells expressing $\triangle$ PRRT2, wtPRRT2 or control GFP in the presence and absence of $10 \%$ FCS. 


\section{Identification of novel MMR target genes in PCa}

A list of 381 genes showing mutations in mononucleotide repeats in PC346C was used to select for novel target gene mutations caused by deficiency in the MMR system in PCa. Since the percentage of PCa cases with MSI was low we extended the test panel to include ovarian, endometrial and colorectal cancer cell lines. A final list of 13 candidate genes was further assessed for their mutation status in cell lines with and without microsatellite instability. We have first selected for the genes with the highest mutation frequencies in our prostate cancer cell line panel. Although TSHZ2 showed the highest mutation frequencies for colorectal and ovarian cancer cell lines only one out of the four MSI prostate cancer cell lines was positive for the TSHZ2 mutation. CNOT1 was mutated in all MSI prostate cancer cell lines but this was, in all cases, an heterozygous mutation and occurred closed to the end of the coding region. Both PRRT2 and DAB2IP were mutated in three out of the four MSI prostate cancer cell lines. Whereas PRRT2 mutations were also frequent in both colorectal, endometrial and ovarian cancer cell lines DAB2IP mutations were mostly restricted to prostate and colorectal cancer samples. DAB2IP has recently been identified as a regulator of tumour growth and apoptosis. The expression of DAB2IP is often downregulated in $\mathrm{PCa}$ and this downregulation causes activation of the RAS signalling cascade and inactivation of the ASK1-JNK pathway leading to growth stimulation and suppression of apoptosis $[42,43]$. The observation that DAB2IP is mutated at high frequency in MMR deficient prostate and colorectal cell lines indicates a link between MMR and this gene. But so far, epigenetic suppression was suggested as the major mechanism behind $D A B 2 I P$ downregulation [44]. Truncating mutations in PRRT2 were first identified in 2011 by Chen WJ et al. in paroxysmal kinesigenic dyskinesia (PKD) [32]. Although PRRT2 appears to be an important factor in several neurological-related conditions [45] there is no correlation between PRRT2 and other diseases. Also, there is little functional data regarding the PRRT2 protein with only one protein-protein interaction known so far with the synaptosomal-associated protein 25 (SNAP25) [46].

\section{PRRT2 and mismatch repair deficiency}

The mutation status of PRRT2 and DAB2IP was assessed in a cohort of 24 colorectal and 24 endometrial MSI patient samples. We observed a high number of patients with mutations in PRRT2 and to a lesser extent mutations in DAB2IP were detected. The finding that $D A B 2 I P$ was mutated in only one endometrial cancer sample indicates tissue specificity for this particular gene mutation. PRRT2 was frequently mutated in both colorectal and endometrial cancer patients. The frequency of PRRT2 mutation in patient samples is only second to the frequency of TGF $\beta$ RII in colorectal cancer and the highest in endometrial cancer of all MSI genes (Supplementary Table 7) [47]. Although most targets of MMR deficiency are considered to be tumor suppressor genes that through the frameshift outcome lose their function there are also studies showing activating mutations such as the frameshifts in the TCF4 gene [48]. The two PRRT2 frameshift mutations found in $\mathrm{PC} 346 \mathrm{C}$, the insertion of one or two Cs, occur in a $\mathrm{C} 9$ repeat in the second coding exon and introduce a premature stop codon in the mRNA. As a consequence, the PC346C cell line lacks a wild type PRRT2 protein. Although it is claimed that the non-sense mediated mRNA decay (NMR) mechanisms recognises premature stop codons and eliminate aberrant transcripts [49] we found a high level of expression of the PRRT2 transcript in the PC346C cell line. The expression level of PRRT2 is overall lower in cancer as compared to normal, which would indicate it as a potential tumour suppressor gene. However mutations in this gene only affect one of the copies in almost all affected cancers, leaving a wild type PRRT2 copy intact. The PC346C prostate cancer cell line and patient from which the cell line is derived are the only samples with homozygous mutations in the 9C repeat. Despite the lower expression of PRRT2 in cancer versus normal tissue our data suggests a dominant negative effect of the truncated PRRT2 protein

\section{PRRT2 in proliferation and migration}

To investigate the functional role of both the wild-type (PRRT2 ${ }^{\mathrm{wt}}$ ) and the truncated PRRT2 protein $(\triangle \mathrm{PRRT} 2)$ we generated stable PRRT2 ${ }^{\mathrm{wt}}$ and $\triangle \mathrm{PRRT} 2$ expressing cell lines. Two normal prostate cell lines (PNT2C2 and RWPE-1) and one colorectal cancer cell line (HCT116) were used to assess the effect of PRRT2 in proliferation, apoptosis and migration. Remarkably, we observed an oncogenic effect of $\triangle$ PRRT2. Both proliferation, migration and invasion were enhanced by stable $\triangle$ PRRT2 expression. Also, the cell cycle profile showed an enrichment of cells in S-phase and lesser cells in G1 suggesting these cells are cycling faster. Conversely, PRRT2 $^{\mathrm{wt}}$ appeared to decrease the proliferation rate, being this effect more evident in the PNT2C2 and HCT116 cell lines as compared to RWPE-1. This decrease in proliferation by PRRT2 ${ }^{\mathrm{wt}}$ overexpression suggests PRRT2 to participate in cell cycle regulation. The frameshift mutation creates a truncated PRRT2 protein that increases both proliferation and migration in cell lines with a wild type PRRT2 protein. Based on our findings, we hypothesize that wild type PRRT2 inhibits slightly proliferation, whereas truncated PRRT2 can stimulate, and overrules wild type PRRT2. In this way it can function as an oncogene by promoting both proliferation and migration. Although genes are usually dichotomized in either oncogenes or tumor suppressors [50] many can actually exert both functions such as the $T p 53$ tumor 
suppressor gene which can lead to tissue invasion, metastasis and increased proliferation when mutated [51].

In conclusion, a focused genome-wide sequencing approach, followed by subsequent expression and functional studies indicate mutated PRRT2 as a novel dominant oncogene, and wtPRRT2 as a candidate tumor suppressor gene. The finding that the same PRRT2 mutation detected in this study has also been documented in colorectal, pancreatic and stomach cancer samples (depicted as A214P in Supplementary Figure 6) supports a more general role of PRRT2 in cancer biology.

\section{MATERIALS AND METHODS}

\section{DNA samples used in whole genome and data analysis}

The DNA of two prostate cancer samples, the PC346C prostate cancer cell line [52] and the G089 prostate cancer patient, were sequenced by Complete Genomics (Complete Genomics Inc, CA). Tissue sample G089 and other patient materials described below has been collected according to national legislation concerning ethical requirements. Use of the clinical samples has been approved by the Erasmus MC Medical Ethics Committee according to the Medical Research Involving Human Subjects Act (MEC-2004-261). NCBI build 36 (hg18) was used as a reference genome during the mapping and data analysis process. Complete Genomics Inc. pipeline generated a report with all single nucleotide variants present in the two samples. Further information on the Complete Genomics Inc. data processing is present in supplementary materials and methods.

\section{DNA from additional cell lines and tissue samples}

Additional genomic DNA was isolated from MMRproficient prostate cancer cell lines PC3, PC135 and PC295 and MMR-deficient prostate cancer cell lines DU145, LNCaP and PC374. Cell pellets from thirteen colorectal, seven endometrial and three ovarian cancer cell lines were kindly provided by Dr. W. Dinjens, Dept Pathology, Erasmus MC, Rotterdam, The Netherlands.

Also, genomic DNA was isolated from frozen 31 primary prostate cancer patient tissues, 37 transurethral resection of the prostate (TURP) samples and 11 lymph node prostate cancer metastasis samples. Genomic DNA from paraffin embedded formalin fixed tissue samples of 24 microsatellite instable colorectal cancer patients and 24 microsatellite instable endometrial cancer patients were kindly provided by Dr. W. Dinjens.

\section{DNA isolation}

DNA isolation from prostate cancer samples was performed using the QIAamp DNA Blood Midi Kit
(Qiagen) according to the manufacturers' instructions. Cell pellets were resuspended in $1 \mathrm{ml}$ PBS (BioWhittaker) and instructions were followed according to the protocol used for $1 \mathrm{ml}$ whole blood. DNA was eluted in $200 \mu \mathrm{l}$ elution buffer.

DNA isolation from the colorectal, endometrial and ovarian cancer cell lines pellets was performed using the Gentra Puregene Cell Kit (Qiagen) (approx. $15 \mu \mathrm{g}$ DNA from 2x106 cells) following the manufacturer's protocol.

Concentration and purity of the DNA was assessed using the NanoDrop ND 1000 spectrophotometer (Nanodrop) by absorption measurements at $260 \mathrm{~nm}$. DNA was stored at -20 degrees Celsius.

\section{RNA isolation}

Total RNA was isolated from PC346C, RWPE1, VCaP, HCT116 and PNT2C2 using the RNeasy kit (Qiagen) according to the manufacturer's protocol. RNA was eluted in $50 \mu \mathrm{l}$ RNase free water. Concentration and purity of RNA was assessed using the NanoDrop ND 1000 spectrophotometer (Nanodrop) by absorption measurements at $260 \mathrm{~nm}$. RNA was stored at -80 degrees Celsius.

\section{Cell culture}

The PC346C cell line was cultured in DMEM-F12 (BioWhittaker), supplemented with $2 \%$ (V/V) FCS (PAN Biotech), 1\% insulintransferrin-selenium (GIBCO BRL), 0.01\% BSA (Boehringer-Mannheim), $10 \mathrm{ng} / \mathrm{ml}$ epidermal growth factor (Sigma-Aldrich) and $500 \mathrm{U}$ penicillinstreptomycin (BioWhittaker), $100 \mathrm{ng} / \mathrm{ml}$ bronectin (Harbor Bio Products), $20 \mathrm{mg} / \mathrm{ml}$ fetuine (ICN Biomedicals), $0.1 \mathrm{nM}$ R1881 (Sigma-Aldrich), $50 \mathrm{ng} / \mathrm{ml}$ cholera toxin (Sigma-Aldrich), $0.1 \mathrm{mM}$ phosphoethanolamine (SigmaAldrich), $0.6 \mathrm{ng} / \mathrm{ml}$ triodothyronine (Sigma-Aldrich), and $500 \mathrm{ng} / \mathrm{ml}$ dexamethasone (Sigma-Aldrich). The PC346C cell line expresses the wild-type androgen receptor and secretes high levels of PSA. RWPE-1 cells were cultured in keratinocyte medium (GIBCO BRL), supplemented with $5 \mathrm{ng} / \mathrm{ml}$ epidermal growth factor, $1 \%$ penicillinstreptomycin (BioWhittaker), and $50 \mathrm{mg} / \mathrm{L}$ bovine pituitary extract. RWPE-1 is a normal prostate epithelium cell line that is androgen-independent and expresses both the androgen receptor and PSA. The colorectal cancer cell line HCT116 and the normal prostate cell line PNT2C2 cells were cultured in RPMI-1640 (GIBCO BRL), supplemented with 10\% FCS (PAN Biotech) and 1\% penicillin-streptomycin (BioWhittaker). All cell lines were cultured at 37 degrees in a 5\% CO2 atmosphere.

\section{Mononucleotide repeat analysis}

A microsatellite instability assay was used to detect changes in the length of mononucleotide repeats by PCR amplification. Primers were designed using the 
Primer3Plus program (http://www.bioinformatics.nl/cgibin/primer3plus/primer3plus.cgi). The final fragment size was set to vary between 100 and $130 \mathrm{bp}$ in order to allow precise fragment sizing and robust amplification of all the genes tested. Primer sequences are described in Supplementary materials and methods. The M13 sequence (GTAAAACGACGGCCAGT) was added at the 5' end of each forward primer. This enabled the use of a M13FAM primer to fluorescently label each PCR fragment. PCR reactions were performed in a total volume of $16 \mu \mathrm{l}$ containing $12.5 \mathrm{ng}$ genomic DNA, $3 \mu \mathrm{l}$ 10x PCR Buffer (Quiagen), $2 \mu 1$ 5x Q-Solution (Quiagen), $0.9 \mu 125 \mathrm{mM}$ $\mathrm{MgCl} 2$ (Quiagen), $0.3 \mu \mathrm{ldNTP}(10 \mathrm{mM}), 0.5 \mu \mathrm{l}$ forward primer (100ng/ $\mu \mathrm{l}), 0.5 \mu \mathrm{l}$ M13-FAM primer (100ng/ $\mu \mathrm{l}), 1 \mu \mathrm{l}$ reverse primer $(100 \mathrm{ng} / \mu \mathrm{l})$, and $1 \mathrm{U}$ HotStarTaq Polymerase (Quiagen). An initial denaturation step of $15 \mathrm{~min}$ at 95 degrees Celsius was used to activate the HotstarTaq, followed by 35 cycles denaturation at 95 degrees Celsius for $30 \mathrm{sec}$, an annealing step at 54 degrees Celsius for $30 \mathrm{sec}$ and elongation at 72 degrees Celsius for $1 \mathrm{~min}$. A final elongation step at 72 degrees Celsius for $10 \mathrm{~min}$ was used. PCR products were checked by electrophoresis in a $1 \%$ agarose gel.

\section{Fragment analysis}

The PCR products were separated by capillary electrophoresis using an ABI PRISM 3130 sequencing analyzer. This method allows single base pair resolution of PCR fragments. A mixture of $1.5 \mu \mathrm{l}$ of the PCR products with $9.8 \mu$ highly-deionized formamide (HiDi) and 0.2 $\mu \mathrm{l}$ GeneScan-500 LIZ size standard (Applied Biosystems) was prepared. This mixture was heated for 2 min at 95 degrees Celsius and subsequently loaded to the sequence analyzer. Data was analyzed with the Peak Scanner software (Applied Biosystems).

\section{Sequencing}

PCR products have been sequenced bi-directionally using standard Sanger sequencing. The sequencing reactions were carried out using the same forward and reverse primers as indicated above in the PCR but at different concentrations ( $3 \mathrm{ng}$ primer per reaction). The final reaction volume was $20 \mu \mathrm{l}$. The sequencing products were precipitated using isopropanol and resuspended in 20 ul formamide (Sigma-Aldrich). The PCR product was sequenced on an ABI Model 3730 automated sequencer and analyzed using DNAMAN (Lynnon Corporation).

\section{PRRT2 expression constructs}

The sequence validated I.M.A.G.E clone IRATp970E0579D corresponding to the BC053594 clone accession number was purchased from Source Bioscience, Nottingham, UK. This plasmid contains the wtPRRT2 cDNA sequence. Primers 5' GAT CGA ATT
CGT TTG CCG CTG TCT CT 3' (Fw) and 5' GAT CGC GGC CGC TCA CTT ATA CAC GCC 3' (Rv) were used to amplify the wtPRRT2 cDNA and subsequently clone the fragment into the pCDH-CMV-MCS-EF1-GFP-T2APuro vector (System Biosciences). Primers 5' GAT CGA ATT CGT TTG CCG CTG TCT CT 3' (Fw) and 5' GAT CGC GGC CGC CCC TTC TCA TTC GAT 3' (Rv) were used to generate a truncated PRRT2 cDNA fragment. This fragment was integrated into the $\mathrm{pCDH}-\mathrm{CMV}-\mathrm{MCS}$ EF1-GFP-T2A-Puro vector (System Biosciences) for expression of $\triangle$ PRRT2 protein. The amplified fragments were ligated to the vector using the Rapid DNA Ligation Kit according to the manufacturer's protocol (Roche). JM109 competent bacteria (Promega) were transformed with the ligation products using the heat shock method and plated in Ampicillin LB agar plates. DNA isolation was performed on selected colonies (Quiagen) and restriction enzyme reactions $\left(\mathrm{BamH}^{\mathrm{I}}\right.$ and $\left.\mathrm{Not}^{\mathrm{I}}\right)$ confirmed the proper ligation of fragment to vector.

\section{Lentivirus production}

HEK293T cells were co-transfected with pCDHwtPRRT2-GFP-Puro or pCDH- $\triangle$ PRRT2-GFP-Puro or pCDH-GFP-Puro expression vectors and pPAX2 and pMD2.G (kind gift of Prof Didier Trono, Switserland) using the calcium phosphate precipitation method. Virus was harvested from the supernatant and used for transduction of PNT2C2, RWPE-1 and HCT116 cells. Pools of infected cells were propagated.

\section{Functional role of PRRT2}

The functional role of PRRT2 was assessed in RWPE-1, HCT116 and PNT2C2 cell lines expressing the truncated form of PRRT2 ( $\triangle \mathrm{PRRT2}$ ), the wildtype PRRT2 (wtPRRT2) and the control GFP. These cell lines were propagated in medium supplemented with $1 \mu \mathrm{g} / \mathrm{mL}$ puromycin (Millipore). Briefly, cells were plated in 96well culture plates at a density of 1000 cells per well (100 $\mu 1)$. Proliferation was assessed using the CellTiter-Glo Luminescent Cell Viability Assay (Promega), according to manufacturer's protocol. Cell cycle analysis was performed by propidium iodide staining of the cell lines involved. Following cell pellet collection, fixation with $70 \%$ ethanol was performed. Fixated cells were washed in PBS- $0.05 \%$ Tween 20 and ressuspended in $500 \mu \mathrm{L}$ of PBS$0.05 \%$ Tween 20 , RNases and PI. Samples were measured in FACS calibre following a 15 minute incubation with PI. Apoptosis was assessed using the ApoLive-Glo ${ }^{\text {TM }}$ Multiplex Assay (Promega), which measures both the number of viable cells as a marker of cytotoxicity and caspase activation as a marker of apoptosis within a single assay well. The assay was performed according to the manufacturer's protocol. As positive control of apoptosis an apoptosis inducer set (Millipore) was used. 
A mix containing 700x dilutions of Actinomycin D (10 $\mathrm{mM})$, Camptothecin (2 mM), Cycloheximide (100 mM), Dexamethasone $(10 \mathrm{mM})$ and Etoposide $(10 \mathrm{mM})$ was supplemented for $24 \mathrm{~h}$ to induce apoptosis. The QCM Chemotaxis Cell Migration Assay, 96-well $(8 \mu \mathrm{m})$, fluorimetric (Millipore) was performed according to the manufacturer's protocol. CytoSelect ${ }^{\mathrm{TM}}$ 24-Well Cell Invasion Assay, Collagen I was used to determine cell invasion according to the manufacturer's protocol.

\section{ACKNOWLEDGMENTS}

We would like to thank Wytske van Weerden, ErasmusMC for PC346C cell line model systems, Complete Genomics Inc. for assistance with the NGS data, Arno van Leenders, Erasmus MC for patient sample selection. This research was made possible by financial contributions from CTMM, project PCMM (project number 03O-203), the FP7 Marie Curie Initial Training Network PRO-NEST (grant number 238278) and the Foundation for Scientific Urological Research (SUWO).

\section{CONFLICTS OF INTEREST}

The authors disclose no potential conflicts of interest.

\section{GRANT SUPPORT}

CTMM, project PCMM (project number 03O-203) FP7 Marie Curie Initial Training Network PRONEST (grant number 238278).

\section{REFERENCES}

1. Li GM. Mechanisms and functions of DNA mismatch repair. Cell Research. 2008; 18:85-98.

2. Shah SN, Hile SE, Eckert KA. Defective mismatch repair, microsatellite mutation bias, and variability in clinical cancer phenotypes. Cancer Research. 2010; 70:431-5.

3. Sharma PC, Grover A, Kahl G. Mining microsatellites in eukaryotic genomes. Trends in Biotechnology. 2007; 25:490-8.

4. Pena-Diaz J, Jiricny J. Mammalian mismatch repair: errorfree or error-prone? Trends in Biochemical Sciences. 2012; 37:206-14.

5. Warren WC, Hillier LW, Marshall Graves JA, Birney E, Ponting CP, Grützner F, Belov K, Miller W, Clarke L, Chinwalla AT, Yang SP, Heger A, Locke DP, et al. Genome analysis of the platypus reveals unique signatures of evolution. Nature. 2008; 453:175-83.

6. Loeb LA. Human cancers express mutator phenotypes: origin, consequences and targeting. Nature Reviews Cancer. 2011; 11:450-7.
7. Markowitz S, Wang J, Myeroff L, Parsons R, Sun L, Lutterbaugh J, Fan RS, Zborowska E, Kinzler KW, Vogelstein B. Inactivation of the type II TGF-beta receptor in colon cancer cells with microsatellite instability. Science. 1995; 268:1336-8.

8. Souza RF, Appel R, Yin J, Wang S, Smolinski KN, Abraham JM, Zou TT, Shi YQ, Lei J, Cottrell J, Cymes K, Biden K, Simms L, et al. Microsatellite instability in the insulin-like growth factor II receptor gene in gastrointestinal tumours. Nature Genetics. 1996; 14:255-7.

9. Guanti G, Resta N, Simone C, Cariola F, Demma I, Fiorente $\mathrm{P}$, Gentile M. Involvement of PTEN mutations in the genetic pathways of colorectal cancerogenesis. Human Molecular Genetics. 2000; 9:283-7.

10. Rampino N, Yamamoto H, Ionov Y, Li Y, Sawai H, Reed JC, Perucho M. Somatic frameshift mutations in the BAX gene in colon cancers of the microsatellite mutator phenotype. Science. 1997; 275:967-9.

11. Schwartz S, Yamamoto $H$, Navarro $M$, Maestro $M$, Reventós J, Perucho M. Frameshift Mutations at Mononucleotide Repeats in caspase-5 and Other Target Genes in Endometrial and Gastrointestinal Cancer of the Microsatellite Mutator Phenotype. Cancer Research. 1999; 59:2995-3002.

12. Riccio A, Aaltonen LA, Godwin AK, Loukola A, Percesepe A, Salovaara R, Masciullo V, Genuardi M, ParavatouPetsotas M, Bassi DE, Ruggeri BA, Klein-Szanto AJ, Testa JR, et al. The DNA repair gene MBD4 (MED1) is mutated in human carcinomas with microsatellite instability. Nature Genetics. 1999; 23:266-8.

13. Duval A, Gayet J, Zhou XP, Iacopetta B, Thomas G, Hamelin R. Frequent frameshift mutations of the TCF-4 gene in colorectal cancers with microsatellite instability. Cancer Research. 1999; 59:4213-5.

14. Alazzouzi H, Davalos V, Kokko A, Domingo E, Woerner SM, Wilson AJ, Konrad L, Laiho P, Espín E, Armengol M, Imai K, Yamamoto H, Mariadason JM, et al. Mechanisms of inactivation of the receptor tyrosine kinase EPHB2 in colorectal tumors. Cancer Research. 2005; 65:10170-3.

15. Liu W, Dong X, Mai M, Seelan RS, Taniguchi K, Krishnadath KK, Halling KC, Cunningham JM, Boardman LA, Qian C, Christensen E, Schmidt SS, Roche PC, et al. Mutations in AXIN2 cause colorectal cancer with defective mismatch repair by activating beta-catenin/TCF signalling. Nature Genetics. 2000; 26:146-7.

16. Hempen PM, Zhang L, Bansal RK, Iacobuzio-Donahue CA, Murphy KM, Maitra A, Vogelstein B, Whitehead RH, Markowitz SD, Willson JK, Yeo CJ, Hruban RH, Kern SE. Evidence of selection for clones having genetic inactivation of the activin A type II receptor (ACVR2) gene in gastrointestinal cancers. Cancer Research. 2003; 63:994-9.

17. Ionov Y, Yamamoto H, Krajewski S, Reed JC, Perucho M. Mutational inactivation of the proapoptotic gene BAX confers selective advantage during tumor clonal evolution. P Natl Acad Sci USA. 2000; 97:10872-7. 
18. Cuilliere-Dartigues P, El-Bchiri J, Krimi A, Buhard O, Fontanges P, Fléjou JF, Hamelin R, Duval A. TCF-4 isoforms absent in TCF-4 mutated MSI-H colorectal cancer cells colocalize with nuclear CtBP and repress TCF-4mediated transcription. Oncogene. 2006; 25:4441-8.

19. de la Chapelle A. Genetic predisposition to colorectal cancer. Nature Reviews Cancer. 2004; 4:769-80.

20. Umar A, Risinger JI, Hawk ET, Barrett JC. Guidelines Testing guidelines for hereditary non-polyposis colorectal cancer. Nature Reviews Cancer. 2004; 4:153-8.

21. Pal T, Permuth-Wey J, Kumar A, Sellers TA. Systematic Review and Meta-analysis of Ovarian Cancers: Estimation of Microsatellite-High Frequency and Characterization of Mismatch Repair Deficient Tumor Histology. Clin Cancer Research. 2008; 14:6847-54.

22. Nelson GS, Pink A, Lee S, Han G, Morris D, Ogilvie T, Duggan MA, Köbel M. MMR deficiency is common in high-grade endometrioid carcinomas and is associated with an unfavorable outcome. Gynecol. Oncol. 2013; 131:309-14.

23. Cancer Genome Atlas Research Network, Kandoth C, Schultz N, Cherniack AD, Akbani R, Liu Y, Shen H, Robertson AG, Pashtan I, Shen R, Benz CC, Yau C, Laird PW, et al. Integrated genomic characterization of endometrial carcinoma. Nature. 2013; 497:67-73.

24. Leite M, Corso G, Sousa S, Milanezi F, Afonso LP, Henrique R, Soares JM, Castedo S, Carneiro F, Roviello F, Oliveira C, Seruca R. MSI phenotype and MMR alterations in familial and sporadic gastric cancer. International Journal of Cancer. 2011; 128:1606-13.

25. Imai K, Yamamoto H. Carcinogenesis and microsatellite instability: the interrelationship between genetics and epigenetics. Carcinogenesis. 2008; 29:673-80.

26. Leach FS, Velasco A, Hsieh JT, Sagalowsky AI, McConnell JD. The mismatch repair gene $\mathrm{hMSH} 2$ is mutated in the prostate cancer cell line LNCaP. J Urology. 2000; 164:1830-3.

27. Chen Y, Wang J, Fraig MM, Metcalf J, Turner WR, Bissada NK, Watson DK, Schweinfest CW. Defects of DNA mismatch repair in human prostate cancer. Cancer Research. 2001; 61:4112-21.

28. Kumar A, White TA, MacKenzie AP, Clegg N, Lee C, Dumpit RF, Coleman I, Ng SB, Salipante SJ, Rieder MJ, Nickerson DA, Corey E, Lange PH, et al. Exome sequencing identifies a spectrum of mutation frequencies in advanced and lethal prostate cancers. P Natl Acad Sci USA. 2011; 108:17087-92.

29. Pritchard CC, Morrissey C, Kumar A, Zhang X, Smith C, Coleman I, Salipante SJ, Milbank J, Yu M, Grady WM, Tait JF, Corey E, Vessella RL, et al. Complex MSH2 and MSH6 mutations in hypermutated microsatellite unstable advanced prostate cancer. Nat Commun. 2014; 5:4988
30. Teles Alves I, Hartjes T, McClellan E, Hiltemann S, Böttcher R, Dits N, Temanni MR, Janssen B, van Workum W, van der Spek P, Stubbs A, de Klein A, Eussen B, et al. Next-generation sequencing reveals novel rare fusion events with functional implication in prostate cancer. Oncogene. 2015; 34:568-77.

31. Woerner SM, Yuan YP, Benner A, Korff S, von Knebel Doeberitz M, Bork P. SelTarbase, a database of human mononucleotide-microsatellite mutations and their potential impact to tumorigenesis and immunology. Nucleic Acids Research. 2010; 38:D682-9.

32. Chen WJ, Lin Y, Xiong ZQ, Wei W, Ni W, Tan GH, Guo SL, He J, Chen YF, Zhang QJ, Li HF, Lin Y, Murong SX, et al. Exome sequencing identifies truncating mutations in PRRT2 that cause paroxysmal kinesigenic dyskinesia. Nature genetics. 2011; 43:1252-5.

33. Hanahan D, Weinberg Robert A. Hallmarks of Cancer: The Next Generation. Cell. 2011; 144:646-74.

34. Wierdl M, Greene CN, Datta A, Jinks-Robertson S, Petes TD. Destabilization of simple repetitive DNA sequences by transcription in yeast. Genetics. 1996; 143:713-21.

35. Peltomaki P. Deficient DNA mismatch repair: a common etiologic factor for colon cancer. Human Molecular Genetics. 2001; 10:735-40.

36. Kagan J, Pisters L, Troncoso P, Joe Y, Parat J, Babaian $\mathrm{R}$, Voneschenbach A. Genetic instability in microsatellite sequences in prostate-cancer. International Journal of Oncology. 1994; 5:921-4.

37. Watanabe M, Imai H, Shiraishi T, Shimazaki J, Kotake T, Yatani R. Microsatellite instability in human prostate cancer. British Journal of Cancer. 1995; 72:562-4.

38. Azzouzi AR1, Catto JW, Rehman I, Larre S, Roupret M, Feeley KM, Cussenot O, Meuth M, Hamdy FC. Clinically localised prostate cancer is microsatellite stable. BJU international. 2007; 99:1031-5.

39. Dahiya R, Lee C, McCarville J, Hu W, Kaur G, Deng G. High frequency of genetic instability of microsatellites in human prostatic adenocarcinoma. International Journal of Cancer. 1997; 72:762-7.

40. Perinchery G, Nojima D, Goharderakhshan R, Tanaka Y, Alonzo J, Dahiya R. Microsatellite instability of dinucleotide tandem repeat sequences is higher than trinucleotide, tetranucleotide and pentanucleotide repeat sequences in prostate cancer. International Journal of Oncology. 2000; 16:1203-9.

41. Kim T-M, Laird Peter W, Park Peter J. The Landscape of Microsatellite Instability in Colorectal and Endometrial Cancer Genomes. Cell. 2013; 155:858-68.

42. Xie D, Gore C, Zhou J, Pong RC, Zhang H, Yu L, Vessella RL, Min W, Hsieh JT. DAB2IP coordinates both PI3K-Akt and ASK1 pathways for cell survival and apoptosis. P Natl Acad Sci USA. 2009; 106:19878-83. 
43. Min J, Zaslavsky A, Fedele G, McLaughlin SK, Reczek EE, De Raedt T, Guney I, Strochlic DE, Macconaill LE, Beroukhim R, Bronson RT, Ryeom S, Hahn WC, et al. An oncogene-tumor suppressor cascade drives metastatic prostate cancer by coordinately activating Ras and nuclear factor-kappaB. Nature Medicine. 2010; 16:286-94.

44. Dote H, Toyooka S, Tsukuda K, Yano M, Ota T, Murakami M, Naito M, Toyota M, Gazdar AF, Shimizu N. Aberrant promoter methylation in human DAB2 interactive protein (hDAB2IP) gene in gastrointestinal tumour. British journal of cancer. 2005; 92:1117-25.

45. Meneret A, Gaudebout C, Riant F, Vidailhet M, Depienne C, Roze E. PRRT2 mutations and paroxysmal disorders. European Journal of Neurology. 2013; 20:872-8.

46. Lee HY, Huang Y, Bruneau N, Roll P, Roberson ED, Hermann M, Quinn E, Maas J, Edwards R, Ashizawa T, Baykan B, Bhatia K, Bressman S, et al. Mutations in the gene PRRT2 cause paroxysmal kinesigenic dyskinesia with infantile convulsions. Cell Reports. 2012;1:2-12.

47. Duval A, Hamelin R. Mutations at coding repeat sequences in mismatch repair-deficient human cancers: toward a new concept of target genes for instability. Cancer Research. 2002; 62:2447-54.
48. Duval A, Rolland S, Tubacher E, Bui H, Thomas G, Hamelin R. The human T-cell transcription factor-4 gene: structure, extensive characterization of alternative splicings, and mutational analysis in colorectal cancer cell lines. Cancer Research. 2000; 60:3872-9.

49. Brogna S, Wen J. Nonsense-mediated mRNA decay (NMD) mechanisms. Nature Structural \& Molecular Biology. 2009; 16:107-13.

50. Lou X, Zhang J, Liu S, Xu N, Liao DJ. The other side of the coin: The tumor-suppressive aspect of oncogenes and the oncogenic aspect of tumor-suppressive genes, such as those along the CCND-CDK4/6-RB axis. Cell Cycle. 2014; 13:0-1.

51. Muller PA, Vousden KH. p53 mutations in cancer. Nature Cell Biology. 2013; 15:2-8.

52. Marques RB, Erkens-Schulze S, de Ridder CM, Hermans KG, Waltering K, Visakorpi T, Trapman J, Romijn JC, van Weerden WM, Jenster G. Androgen receptor modifications in prostate cancer cells upon long-term androgen ablation and antiandrogen treatment. International Journal of Cancer. 2005; 117:221-9. 